\title{
Medicinal Plants Used for Treatment of Psychiatric Disorders in Unani Medicine
}

\begin{abstract}
Azma Waseem ${ }^{1 *}$, Usama Akram², Waseem Ahmad ${ }^{3}$ and M Fazil ${ }^{4}$
${ }^{1}$ Research Officer, S-III, Hakim Ajmal Khan Institute for Literary and Historical Research in Unani Medicine, (CCRUM, Ministry of AYUSH, Government of India), New Delhi, India ${ }^{2}$ Research Officer, Hakim Ajmal Khan Institute for Literary and Historical Research in Unani Medicine, (CCRUM, Ministry of AYUSH, Government of India), New Delhi, India ${ }^{3}$ Technical Officer, Hakim Ajmal Khan Institute for Literary and Historical Research in Unani Medicine, (CCRUM, Ministry of AYUSH, Government of India), New Delhi, India ${ }^{4}$ In charge, Research Officer, S-IV, Hakim Ajmal Khan Institute for Literary and Historical Research in Unani Medicine, (CCRUM, Ministry of AYUSH, Government of India), New Delhi, India

*Corresponding Author: Azma Waseem, Research Officer, S-III, Hakim Ajmal Khan Institute for Literary and Historical Research in Unani Medicine, (CCRUM, Ministry of AYUSH, Government of India), New Delhi, India.
\end{abstract}

Received: April 23, 2020

Published: May 12, 2020

(C) All rights are reserved by Azma

Waseem., et al.

\section{Abstract}

The term mental disease is not restricted to mean insanity and allied conditions of mental derangement but also includes, to a certain extent, the emotional disorders. When emotional factors cross the state of normalcy, one gets deranged to show the syndromes of mental disorder, very often. These pathologies affect all categories of person, race, sex and age. Many synthetic psychoactive molecules such as antiepileptic, antidepressants, anxiolytics are used in modern medicine to treat these pathologies. But allopathic medicine is not found very effective. Further, cost, dependency on diagnostic tools, increasing adverse effects and symptomatic rather than curative approach of allopathic medicine made the world population seeking an alternative medical system. Currently, the world is looking towards traditional medicines, including Unani pathy for a reliable cure for psychiatric disorders. Little research has approached the specific case of plants used to treat nervous system disorders. It is necessary to report psychic disorders treated by medicinal plants in Unani Medicine. It is high time to look back to the Unani system of medicine wherein a number of plants and mineral origin drugs have been described for specific uses for a range of mental disorders. An attempt has been made in this paper to highlight the beneficial Unani plant origin drugs in psychiatric problems. These plants have been reported for their potential in treating many neuropsychiatric problems. Some research studies conducted on the scientific parameters on the plant drugs will also be provided to show the potential of these drugs which may help in development of new intervention or a substitute for conventional drug, or that can be used as an adjuvant.

Keywords: Psychiatric Disorders; Unani Medicine; Adjuvant; Amraz-I Nafsaniya

\section{Introduction}

According to the World Health Organization (WHO), neuropsychiatric disorders are a whole of "mental health problems", which are characterized by anomalies of the thought, emotions, behavior and relationship with others [1]. It results in inability to perform or cope up with demands and routine of life. The term mental disease is not restricted to mean insanity and allied conditions of mental derangement but also includes, to a certain extent, the emotional disorders. When emotional factors cross the state of normalcy, one gets deranged to show the syndromes of mental disorder, very often. Factors causing these disorders are essentially genetic, social, environmental and psychotropic drugs. Mental and neurological disorders represent $13 \%$ of the burden of total morbidity in the world. The prevalence of psychiatric illness is almost same in India and the West, about 8 to 10 per 1000 population. During the whole life time about 25 percent persons suffer from psychological health issues [2]. Depression, insomnia and anxiety disorders also affect the other systems of the body such as they impair the function of immune and cardiovascular systems [3]. The World Health Organization anticipated that depression will be the second leading cause of infirmity in 2020. Epilepsy is one of the most common neurological disorders that has affected more than 50 million persons in the world including $80 \%$ in developing countries [4]. 
Many psychoactive molecules such as antiepileptic, antidepressants, anxiolytics are used in modern medicine to treat mood, depressive and other psychotic disorders. But allopathic medicine is not found very effective. Further, cost, dependency on diagnostic tools, increasing adverse effects and symptomatic rather than curative approach of allopathic medicine made the world population seeking an alternative medical system.

It is high time to look back to the ancient Unani medical literature wherein a number of plants origin drugs have been described for specific uses for a range of mental disorders, including convulsion, hysteria, paralysis, dementia, insomnia, anxiety, insanity, depression, etc.

In the Unani system of medicine, psychiatric problems are dealt in detail under the heading of 'Amraz-i Nafsaniya'. Ibn Sina clearly classified the mental or psychiatric diseases due to disturbance or weakness of special powers of mental faculties (Quwa Nafsani) [5]. Majusi classified these special powers as Imaginative power/ faculty (Quwwat-i Mutakhayyala), Thinking faculty (Quwwat-i Mufakkira) and memory (Quwwat-i Zakira or Quwwat Hafiza) [6]. The centre of these powers lies in the brain and perform planning, imagination, thinking and memory functions [5,7]. The main causative factors for psychiatric disorders are the ill temperament of brain (Su-i Mizaj), the quantitative or qualitative changes in humors particularly morbid black bile (Ghayr Tabai Sawda) and loss of continuity (Tafarruq-i Ittesal) [5] which produces sadness, negative thoughts, hallucination, delusion, mood swings, grief, etc. and discussed under the disease called malikhuliya (depression) [8]. Forgetfulness and dementia occurs due to changes in brain due to old age (Alziemer's disease), accumulation of morbid phlegm in the brain [9] and excessive dryness causes insomnia [10] (Ibn Hubal Vol III). Accumulation of morbid matter in the brain produces weakness or disturbance of mental faculties giving rise to various mental health issues. Awariz-i Nafsaniya (emotions/psychic reaction) produce movement in the Ruh (pneuma) through blood. The movement of Ruh is seen outward or inward in emotions. The movement of ruh is outward and sudden as in anger and is outwards and gradual as in happiness. The movement of ruh is inward and sudden as in fear and inwards and gradual as in sadness. This movement of increases the heat in part towards it flow leaving the other part cold. When the cycle of heat and cold becomes excessive, it affects various organs of the body and results in occurrence of disease [6].

The basic principles of the Unani treatment for psychiatric disorders includes: The correction of temperament of the brain (Tadeel-i Mizaj) [5,9]; Evacuation of morbid matter (Istifragh) [5]; To produce exhilaration (Tafreeh-i Taba) $[10,11]$. To strengthen brain and heart (Taqwiyat-i Dimagh wa Qalb) [9]; Analgesia to re- lief pain (Taskeen); To induce sleep (Tanwaeem) [5]; physical and mental rest (Sukoon-i Jismani wa Nafsani) and removal of the causative factor [5,9]. For the treatment of mental diseases mainly three treatment modules i.e. dietotherapy, regimenal therapy and pharmacotherapy are mainly used in Unani medicine. In the pharmacotherapy module, various plants origin drugs are mentioned by for the treatment of psychiatric ailments. Some drugs influenced the nervous system by exerting special pharmacological actions which are still unknown (Zul Khassa) are also included [12]. According to Unani physicians, evacuation of morbid matter (Istafragh) is done with Munzijat (maturative) or Mushilat (purgative) drugs and use of emolient (Mulattifat), resolvants (Muhallilat), drugs to remove the morbid matter. Drugs which have refrigerant (Mubarrid), moistness producing (Murattib) heat producing (musakhkhin) activities helps in alteration of temperament, and drugs that show exhilarant (Mufarreh) action play an important role in psychiatric diseases [9]. Ibn Sina has advocated the drugs that increases the substance (Jawhar) of brain, purify the brain (Munaqqi-i Dimagh), hypnotics (Munawwimat), brain tonics (Muqawwi-i Dimagh), drugs that improves cognitive functions like (Muqawwi-i hawaas and Muqawwi-i Zehan/AqI), Muqawwi-i Qalb (heart tonic), Muharrik-i Dimagh wa Asaab (stimulants of brain and nerve), memory enhancers (Muqawwi-i Hafiza) [14]. To some extend blood purifiers (Musaffiyat-i dam) with adoption of psychic measures in the management of psychiatric ailments $[9,13]$. The drugs which prevent production and movements of gaseous substance towards the brain from other organs of the body are also advocated for the treatment if mental problems are secondary to other diseases such as psychosis (Malankhulia miraqi) [13,14].

Some single drugs useful for mental health promotion and psychoneurotic diseases

Aftimoon (Cuscuta epithymum Linn.) [12,14-19]

- $\quad$ Part used: Whole plant $[18,19]$.

- Its temperament is hot and dry-3 [14].

- Pharmacological action: Melanogogue (Mushil-i Sawda) [14-16], diuretic (Mudir-i Baul) [19].

- Therapeutic uses: It is effective for melancholia (Malankhuliya) [14], insanity/Schizophrenia (Junoon/Waswas) and epilepsy (Sara) [12], nightmares (Kaboos), Falij (paralysis), Laqwa (Facial palsy) and Khadr (numbness) $[15,17,18]$.

- Dose: 7 gm [14] and decoction- 14 gm [14]; decoction$17.5-24.5 \mathrm{gm}$ and $17 \mathrm{gm}$ with honey to induce purgation [15].

- Pharmacological studies:

- Anticonvulsant activity [20].

- Anxiolytic [21]. 


\section{Asgand (Withania somnifera Linn.) [19,22]}

- $\quad$ Part used: Root [19].

- Its temperament is hot-3, dry-3 [19].

- $\quad$ Pharmacological action: It is memory enhancer (Muqawwii Hafiza), nervine tonic (Muqawwi-i Asab) and health preservative (Muhafiz-i Sehat) [22].

- Therapeutic uses: It is useful for Nasayan (forgetfulness) and corrects phlegmatic derangement and blood impurities [22].

- Dose: 1 gm with milk [22].

- Pharmacological studies:

- $\quad$ Mood stabilizer [23].

- Anti-stress activity [24].

- Anxiolytic and antidepressant activity [25].

\section{Bisfayij (Polypodium vulgare Linn.) $[16,19,26]$}

- $\quad$ Part used: Root [19].

- Its temperament is hot-2, dry-3 [16].

- Pharmacological action: It is purgative of black bile and phlegm (Mushil-i Sawda wa Balgham) [16], exhilarant (Mufarreh), cardiac tonic (Muqawwi-i Qalb), brain tonic (Muqawwi-i Dimag) [16,19], blood purifier (Musaffi-i Khoon) [22] and analgesic (Musakkin) [13].

- Therapeutic uses: It is useful for insanity/schizophrenia (Junoon), melancholia/depression (Malikhuliya) [19,26] and epilepsy (Sara) $[27,28]$.

- Dose: Upto 5 gm [22]; 5 - 10 gm [27]; 3 - 11 gm [28].

- Pharmacological studies:

- Analgesic activity [29].

- Antiepileptic [29].

- Antipyretic [29].

- Neuro psychopharmacological activity [29].

Amlaj/Amla (Embellica officinalis) $[14,15,18,30]$

- Part used: Fruit [30].

- $\quad$ Its temperament is cold and dry-2 $[15,17]$.

- Pharmacological action: It is blood purifier (Musaffi-i Khoon), melanogogue (Mukhrij-i Sawda), brain and nerve stimulant (Muharrik-i Dimagh wa Asaab), brain tonic (Muqawwi-i Dimagh), cardiac tonic (Muqawwi-i Qalb), and stomachic (Muqawwi-i Meda) [31].
- Therapeutic uses: Melancholia/depression (Malikhuliya) [30], cerebral asthenia (Zof-i Dimagh) and palpitation (Khafqan) [31].

- $\quad$ Dose: 3 - 5 gm [31].

- Pharmacological studies:

- Antidepressant and antioxidant [32].

Badranjboya (Nepeta hindostana Haines) [15-17,26,31,33]

- $\quad$ Part used: Leaf and seed [31].

- Its temperament is hot and dry-2 [33].

- Pharmacological action: It is concoctive of black bile (Munzij-i Sawda), exhilarant (Mufarreh) [26,33], blood purifier (Musaffi) [15,31], brain tonic (Muqawwi-i Dimagh), cardiac tonic (Muqawwi-i Qalb) [16,17], deobstruent (Mufatteh Sudad), enhances memory and intellect [31]. It is useful for anxiety (Ham) [26], palpitation (Khafqan), paralysis (Falij) and epilepsy (Sara) [17], Insomnia (Sahar) [16] and hypertension (Fisharuddam) [34], dementia (Nisyan) and vertigo (Duwar) [35].

- Dose: 5 - 7 gm [31]

- Pharmacological studies:

- Anxiolytic activity [36].

Brahmi (Bacopa monnieri (Linn.) Penn.) [18,19,31,37]

- $\quad$ Part used: Whole plant [19].

- Its temperament is hot-1 and dry [37].

- Pharmacological action: It is Muqawwi-i Dimagh (brain tonic) [37], increases intelligence and sharpens memory $[19,22,31]$.

- Therapeutic uses: It is useful for melancholia/depression (Malikhuliya) [37] and insanity/schizophrenia (Junoon) [22,37].

- Dose: 3 - 5 gm [19,31].

- Pharmacological studies:

- Memory enhancer and improves brain function (learning) [38].

- Cognitive function enhancer [39].

- Antioxidant activity and antinociceptive [40]

- Anxiolytic activity [41].

- Anti-stress activity [42]. 


\section{Halayla (Terminalia chebula Retz.) $[14,26,43,44]$}

- $\quad$ Part used: Fruit/fruit rind $[14,26]$.

- $\quad$ Temperament of Halayla Siyah wa Zard is cold and dry [43] and Halayla Kabuli is moderate [18,44].

- Pharmacological action: It is purgative of black bile (Mushil-i Sawda), strengthens brain, memory and senses $[18,27,44]$ and stomachic (Muqawwi-i Meda) [22].

- Therapeutic uses: It is useful for facial paralysis (Laqwa), epilepsy (Sara), melancholia/depression (Malankhuliya/Malikhuliya), illusion/psychosis (Waswas), insanity/schizophrenia (Junoon), palpitation (Khafqaan) and headache (Suda) $[14,27,43,44]$.

- Dose: 3 - 5 gm [22]; 5-10 gm [24].

- Pharmacological studies:

- Antioxidant activity [45].

- Anticonvulsant [46].

- Antidepressant [47].

- Antidepressant and anxiolytics activity [48].

- Neuroprotective [49].

Lisan al-Saur/Gauzaban (Borago officinalis) [15,17,19,26]

- $\quad$ Part used: Leaf, flower, root $[15,19]$.

- Its temperament is hot and wet $[17,19]$.

- Pharmacological action: It is melanogogue (Mushil-i Sawda) [15,26], Mufarreh (exhilarant) [27], Muqawwi (tonic) of vital organs [17], sharpens senses, improves intelligence, demulscent (Mulattif) and brain and cardiac tonic (Muqawwi-i Dimagh wa Qalb) [19]. It is useful for melancholia/depression (Malikhuliya), insanity/scizophrenia (Junoon), grief/sadness (Gham) and anxiety (Ham) $[15,17,26]$.

- Dose: 5 - 10 gm [19].

- Pharmacological studies:

- Memory enhancer/Alzheimer's disease [50].

- $\quad$ Antidepressant [51].

Saad/Saad Kufi (Cyperus rotundus Linn.) [14,15,19,52]

- $\quad$ Part used: Rhizome/root $[14,19]$.

- Its temperament is hot-2 and dry-2 [52].
- Pharmacological action: It is deobstruent (Mufatteh sudad), descicant (Mujaffif) brain tonic (Muqawwi-i Dimagh) [52], enhances memory [14,15] and increases intelligence [52].

- Therapeutic uses: It is useful for weakness of brain/cerebral asthenia (Zof-i Dimagh), weakness of memory (Zof-i Hafiza) and other neurological diseases [52].

- Pharmacological studies:

- $\quad$ Antidepressant [53].

- Neuroprotective and cognitive function enhancer [54].

Sankhahuli (Convolvulus pluricaulis Chois.) [18,19,52]

- $\quad$ Part used: Seed [52] and root [31].

- Its temperament is cold and wet $[31,52]$.

- Pharmacological action: It is blood purifier (Musaffi-i Khoon) [31], laxative (Mulayyin) and memory enhancer [52], improves intelligence and cognitive functions of brain [18,19], psycho-stimulant and tranquilizer [55].

- Therapeutic uses: It is useful for Malikhuliya (melancholia) [19], Sara (epilepsy) and reduces mental tension [55].

- $\quad$ Dose: 3 gm [19] KA, 7 - 10 gm [31].

- Pharmacological studies:

- Antihypertensive [55].

- Anxiolytic [56].

- Anti-stress activity [57].

Sunbul al-Teeb/Balcchar (Nardostachys jatamansi DC.)

$[12,14,19,52]$

- Part used: Root [52].

- Its temperament is hot- 1, dry-2 [14] and according to some hot, dry-2 [52].

- Pharmacological action: It is brain and cardiac tonic (Muqawwi-i Dimagh wa Qalb), exhilarant (Mufarreh) and liver tonic (Muqawwi-i Kabid) [19,52].

- Therapeutic uses: It is useful for palpitation [14] and melancholia/depression (Malikhuliya) [12].

- Dose: 9 gm $[19,52]$.

- Pharmacological studies:

- $\quad$ Antidepressant activity [58]. 
Ward/Gul Surkh (Rosa damascena Mill.) [18,19,26,43,59]

- $\quad$ Part used: Flower/buds/pollens [19].

- Its temperament is Murakkab al-Quwa (compound) [18,43], cold -1 and dry-2 [14].

- Pharmacological action: It is brain tonic (Muqawwi-i Dimagh) [18,19], exhilarant (Mufarreh) [31], purgative of bile (Mushil-i Safra) [26,43], cardiac and liver tonic (Muqawwi-i Qalb wa kabid) and strengthens pneuma [59].

- It is useful for Suda (headache), Khafqan (palpitation) and Sara (epilepsy) [14,19,59].

- Dose: 5 - 7 gm [31].

- Pharmacological studies:

- Antidepressant activity [60].

- Anticonvulsant activity $[61,62]$.

- Anti-stress activity and anti-hypertensive [63].

\section{Conclusion}

Plant origin drugs have an important place in Unani system of medicine. Medicinal plants constitute the base of health care system. The recovery of the knowledge and practices associated with these drugs are part of an important strategy linked to the conservation of biodiversity, discovery of new medicines, and the bettering of the quality of life of the mentally ill people. This review paper present the pharmacological actions and therapeutic uses of some single plant origin drugs useful for mental or psychiatric diseases present in Unani literature supported with the available clinical and animal studies ebdouvering to highlight the research work of Unani physicians in the field. The pharmacological effects exhibited by this plant have been elaborated in depth with citations from studies that have been conducted on these plant drug. However, problems related to the efficacy, of the isolation techniques and stability of bioactive compounds too needs to be addressed. Emphasis should be laid to investigate plant species that have not been the subject of pharmacological studies, although their popular uses have been reported.

\section{Bibliography}

1. WHO. Mental health (2018).

2. Roy RN., et al. "Textbook of Preventive and Social Medicine". $4^{\text {th }}$ edition. Jaypee Brothers Medical Publishers (P) Ltd, New Delhi (2013): 642-649.

3. Taylor DJ., et al. "Insomnia as a health risk factor". Behavioral Sleep Medicine 1.4 (2003): 227-247.
4. World Health Organization (WHO). "Mental Health Gap Action Programme: Scaling up Care for Mental, Neurological, and Substance Use Disorders". WHO: Geneva, Switzerland (2008).

5. Ibn Sina. Al-Qanoon fi al-Tibb, Volume III part I (A), Jamia Hamdard, New Delhi (1989): 8, 19, 21-31, 83-85.

6. Majusi MA. Kamil al-Sana fi al-Tibb, Volume I (A), Central Council for Research in Unani Medicine, New Delhi 216 (2005): 9397.

7. Ibn Rushd. Kitab al-Kulliyat (A), Central Council for Research in Unani Medicine, New Delhi (1984): 40.

8. Al-Razi ABZ. Al-Hawi fi al-Tibb, Volume I (A), Daira Ma'arifa Usmania, Hyderabad (1955): 96-97.

9. Khan MA. Ikseer-i Azam, Volume I (P), Matba Nami Munshi Naval Kishor Lucknow. NM 185.

10. Baghdadi I H. Kitab al-Mukhtarat, Volume III (A), Daira Maarifa Usmaniya, Hyderabad (1363): 30.

11. Al-Qamri N. Ghina Muna, CCRUM, New Delhi (2008): 15-18.

12. Jurjani I. Zakhira Khwarizm Shahi, Volume 10, (Urdu translation), Matba Munshi Naval Kishore, Kanpur (1889): 7-9.

13. Majusi MA. Kamil al-Sana fi al-Tibb, Central Council for Research in Unani Medicine, New Delhi 18 (2005): 262-267.

14. Ibn Sina. Al-Qanoon fi al-Tibb, Jamia Hamdard, New Delhi (1987): 52.

15. Baghdadi I H. Kitab al-Mukhtarat, Daira Ma'arifa Usmania, Hyderabad (1364): 139.

16. Ibn Baitar. Al-Jami Li Mufradat al- Advia wa al-Aghziya, Volume I, Central Council for Research in Unani Medicine, New Delhi 73 (1985): 94-96.

17. Shirazi MMH., Makhzan al-Advia, Matba Ahmadi, Shahdara, Delhi 1278 AH: 89-90, 109, 127, 562-563.

18. Nabi G. Makhzan al-Mufradat wa Murakkabat, Central Council for Research in Unani Medicine, New Delhi (2007): 34, 41, 64, 149, 204, 247.

19. Ghani NM. Khazain al-Advia, Idara Kitab al-Shifa, Delhi. NM: $366,839,1116,1135$.

20. Gupta M., et al. "Studies on brain biogenic amines in methanolic extract of Cuscuta reflexa Roxb and Linn seed treated mice". Acta Poloniae Pharmaceutica-Drug Research 60.3 (2003): 207210 
21. Thomas S., et al. "Evaluation of anxioltic effect of whole plant of "Cuscuta reflexa". World Journal of Pharmacy and Pharmaceutical Sciences 4.8 (2015): 1245-1253.

22. Safiuddin SS. Unani Mufradah Advia, Taraqqi Urdu Bureau, Delhi (1993): 33, 74-75.

23. Attari M., et al. "Effect of Withania somnifera Dunal Root Extract on Behavioral Despair Model in Mice: A Possible Role for Nitric Oxide". Acta Medica Iranica 54.3 (2016): 165-172.

24. Khare CP. "Indian Medicinal Plants-An Illustrated Dictionary". $1^{\text {st }}$ edition. New York: Springer (2007): 652-665, 717-718.

25. Ninadh Malrina D'Costa., et al. "Antidepressant Activity of Ethanolic Extract of Whole Plant of Ashwagandha (Withania somnifera), a Popular Medicinal Plant of Indian Subcontinent". Asian Journal of Biological and Life Sciences 3 (2012): 247-251.

26. Antaki D. Tazkira Ulil al-Baab, Volume I (A), Printed by Central Council for Research in Unani Medicine, New Delhi (2008): $114,122,137-138,531,642$.

27. Said HM. "Hamdard Pharmacopoeia of eastern medicine". Sri Satguru Publications (1977): 985-988.

28. Hakeem MA. "Bustan al- Mufradat, Musawwar Edition". Idara Kitabus-Shifa New Delhi (2002): 92.

29. Mannan A., et al. "Pharmacodynamic studies on Polypodium vulgare L". Indian Journal of Experimental Biology 27 (1989): 556-560.

30. Al-Razi ABZ. Al-Hawi fi al-Tibb, Volume 20, (A), Daira Ma'arifa Usmania Hyderabad (1965): 106.

31. Kabiruddin M. Makhzan al-Mufradat, Maroof ba Khawas alAdvia, Aijaz Publishing house, Urdu bazar Lahore. NM: 55, 109, 112, 127-128, 359-360, 490.

32. Dhingra D., et al. "Possible involvement of monoaminergic neurotransmission in antidepressant like activity of Emblica officinalis fruits in mice". CNS Neuroscience and Therapeutics 18 (2012): 419425.

33. Khan MA. Muheet-i Azam, Volume I, (P), Matba Nizami, Kanpur (1303): 244-245.

34. Lubhaya RH. Bayan al-Advia, Volume I, Goswami Kutub khana, Delhi. NM: 122.

35. Hakeem A. Mufradat-i Azeezi (Urdu), Matbua Sahitya Mandir Press Ltd. Lucknow (1948): 83, 86.
36. Bora KS and Dubey A. "Evaluation of anti-anxiety activity of M parviflora (Benth.) in rats". The Thai Journal of Pharmaceutical Sciences 39.3 (2015): 70-75.

37. Khan MS. Taleef Shareefi, Akmal al-Mataba, Delhi (1847): 36.

38. Achliya G., et al. "Effect of Brahmi Ghrita, a polyherbal formulation on learning and memory paradigms in experimental animals". Indian Journal of Pharmacology 36.3 (2008): 159-162.

39. Nathan PJ., et al. "The acute effect of an extract of Bacopa monniera (Brahmi) on cognitive functions in healthy normal subjects". Human Psychopharmacology Clinical and Experimental 16 (2001): 345-351.

40. Biswas SK., et al. "Evaluation of antinociceptive and antioxidant activities of whole plant extract of Bacopa monniera". Research Journal of Medicinal Plant 6.8 (2012): 607-614.

41. Anju. "Bacopa monnieri - a preliminary study evaluating its anti-stress activity in Swiss albino mice". Research Journal of Pharmaceutical, Biological and Chemical Sciences 2.4 (2011):786-794.

42. Kathryn E Wellen and Gokhan S Hotamisligil. "Inflammation, stress, and diabetes". Journal of Clinical Investigation 115.5 (2005): 1111-1119.

43. Razi ABZ. Al-Hawi fi al-Tibb, Volume 21, part II (A), Daira Ma'arifa Usmania, Hyderabad (1968): 626-628, 637.

44. Al-Attar Z A. Ikhtiyaraat Badeei, Matbanami Munshi Naval Kishor, Kanpur (1888): 45.

45. CL Lin CS. "Development of antioxidant activity and pattern recognition of Terminalia chebula Retzius extracts and its fermented products". Hung Kuang Journal 61 (2010): 115-129.

46. Kumar B., et al. "Anticonvulsant activity of ethanolic extract of fruits of Terminalia chebula on experimental animals". International Journal of Drug development and Research 2.4 (2010): 764-768.

47. Chandra SR., et al. "Antidepressant activity of aqueous extract of Terminalia chebula in rats". International Journal of Pharmacy and Pharmaceutical Sciences 4.4 (2012): 449-451.

48. Onasanwo SA., et al. "Antidepressant and Anxiolytic Potentials of Chebulinic Acid in Laboratory Rodent". Annals of Depression and Anxiety 1.7 (2014): 5.

49. Chialin C and CheSan L. "Phytochemical composition, Antioxidant activity and Neuroprotective effect of $T$ chebula Retz. Extracts". Evidence -Based Complementary and Alternative Medicine (2012): 1-7. 
50. Fatemeh G., et al. "Protective Effects of Borago officinalis Extract on Amyloid $\beta$-Peptide(25-35)-Induced Memory Impairment in Male Rats: A Behavioral Study". BioMed Research International (2014): 8.

51. Cathy JF., et al. "Effectiveness of treatments for depression in older people". Medical Journal of Australia 182 (2005): 627632.

52. Khan MA. Muheet-i Azam, Volume-III, (P), Matba Nizami Kanpur (1313): 34-35.

53. S Zhou Z., et al. "Phenolic glycosides from the rhizomes of $\mathrm{Cy}$ perus rotundus and their antidepressant activity". Journal of Korean Society for Applied Biological Chemistry 58.5 (2015): 685-691.

54. Sutlangka C and Wattanathorn J. "Neuroprotective and cognitive-enhancing effects of the combined extract of Cyperus rotundus and Zingiber officinale". BMC Complementary and Alternative Medicine (2017): 135.

55. Rizwan M and Khan AA. "Assessment of efficacy of Sankhahuli (Convolvulus pluricaulis Chois.) and gokhru (Tribulus terrestris L.) in the management of hypertension". Indian Journal of Traditional Knowledge (IJTK) 13.2 (2014): 313-318.

56. Shamsi Y., et al. "A Clinical study on the management of anxiety neurosis with sankhaholi". Indian Journal of Traditional Knowledge 6.4 (2007): 668-677.

57. Gupta P., et al. "Anti-stress Constituents of Evolvulus alsinoides, An Ayurvedic Crude". Chemical and Pharmaceutical Bulletin 55 (2007): 771.

58. Dhingra D and Goyal P K. "Inhibition of MAO and GABA: Probable mechanisms for antidepressant-like activity of $N$. jatamansi DC in mice". Indian Journal of Experimental Biology 46 (2008): 212-218.

59. Ibn Baitar. Al-Jami li Mufradat al-Adviya wa al-Aghziya, Volume III, Central Council for Research in Unani Medicine. New Delhi (1999): 189-190.

60. Dolati K., et al. "Antidepressant-like effect of aqueous extract from Rosa damascena in mice". Avicenna Journal of Phytomedicine 1.2 (2011): 91-97.

61. Homayoun M., et al. "Anticonvulsant and neuroprotective effects of Rosa damascena hydro-alcoholic extract on rat hippocampus". Avicenna Journal of Phytomedicine 5.3 (2015): 260270 .
62. Kheirabadi M., et al. "Evaluation of the Anti convulsant activities of Rosa damascena on the PTZ Induced Seizures in Wistar Rats". Journal of Biological Sciences 8.2 (2008): 426-430.

63. Kwon E-K., et al. "Flavonoids from the buds of Rosa damascena inhibit the activity of 3-hydroxy-3-methylglutaryl-coenzyme a reductase and angiotensin I-converting enzyme". Journal of Agricultural and Food Chemistry 58 (2009): 882-886.

\section{Assets from publication with us}

- Prompt Acknowledgement after receiving the article

- Thorough Double blinded peer review

- Rapid Publication

- Issue of Publication Certificate

- High visibility of your Published work

Website: www.actascientific.com/

Submit Article: www.actascientific.com/submission.php Email us: editor@actascientific.com

Contact us: +919182824667 